Note

淡水底泥におけるDNA，RNA および核酸分解活性の分布

田畑真佐子・渡辺昇 -今川 直美 - 鈴木 静夫

\title{
Distributions of DNA, RNA and Nucleic Acid Decomposition Activity in Bottom Sediments
}

\author{
Masako Tabata, Noboru Watanabe, Naomi Imagawa and Shizuo Suzuki
}

\begin{abstract}
The distributions of nucleic acids (DNA and RNA) and enzymatic activity of nucleic acid decomposition were measured for four water bodies. The DNA and RNA contents in the four sediments ranged from 3.6 to $81.4 \mu \mathrm{g} \cdot \mathrm{g}^{-1}$ and from 1100 to 2318 $\mu \mathrm{g} \cdot \mathrm{g}^{-1}$ dry sediment, respectively. The contents were larger in the sediment of water bodies containing much chlorophyll-a. Phosphorus in the nucleic acid fraction accounts for 9-24\% of the total phosphorus in the sediments.

Enzymatic activity of nucleic acids decomposistion was measured by incubating the sediment sample in which DNA or RNA was added artificially as substrate and chloroform as a growth inhibitor against microorganisms in the sediments. DNA was decomposed by the incubation with Ushigomebori sediment and RNA was decomposed by Ushigomebori and Teganuma sediments.

Gel chromatography of the incubation mixture showed that phosphorus-free low molecular weight compounds and ortho-phosphate were formed in the DNA or RNA decomposition. The decomposition of DNA and RNA was greater in weak alkaline conditions than acidic conditions, and increased with the rise of temperature.
\end{abstract}

Key words: DNA, nuclease, RNA, sediment

\section{1.はじめに}

リンは世界各地の湖沼での富栄養化現像の主要 因とされており，底泥から湖水中へのリンの供給 に関しても多くの研究がある（例えば MORTIMER, 1971；細見・須藤，1979；小林・西村，1988a， 1988 b)。しかし，それらの多くは無機態リンを対 照としたものである。一方，自然界の有機態リン として, 森林や畑土壤中にはリン脂質, リンタン パク質類，リンアミド類，核酸類等の存在が確認 されているので (スタム・モーガン, 1970), 湖沼 の底泥にもこれらの存在が予想される。底泥中の 有機態リンに関しては，海洋底泥におけるDNAの
分布と分解活性を調べた例 (MAEDA and TAGA, 1973，1974）や，底泥抽出物中の高分子の有機態 リンの存在をクロマトグラフィーにより検討した 例 (SommERS et. al., 1972：中島・金子, 1988) 等 があるが，わが国の淡水底泥における有機リン化 合物の分布とそれらの分解活性に関する情報は寺 しい。

著者らは有機態リンのうち核酸のDNA，RNA に注目し, いくつかの淡水域の底泥での分布及び 核酸分解活性の調查を行ったので報告する。 


\section{2. 実験方法}

\section{2-1. 試料}

湖底泥は 1988 年, 牛込濠（東京都新宿区，採 取水深 $1.5 \mathrm{~m}, 5$ 月 9 日採取), 手賀沼 (千葉県 我孫子市, 採取水深 $1 \mathrm{~m}, 10$ 月 8 日採取), 震生 湖（神奈川県査野市, 採取水梁 $8.5 \mathrm{~m}, 6$ 月 29 日採取), 赤城大沼 (群馬県赤城山, 採取水深 10 $\mathrm{m}, 7$ 月 8 日採取）の湖心にてエクマンバージ採泥 器を用いて採取した。底泥は $4^{\circ} \mathrm{C}, 3000 \mathrm{rpm}$ $(1000 \times g)$ で 30 分問遠心分離して間吵水を除去 し，沈殿を試料とした。

\section{2-2. 底泥の核酸, リンの定量法}

底泥中のDNA, RNAの抽出は, STS 法 (SCHNEIDER, 1946) に準じて行った。概要を Figure 1 に示す。得られた核酸画分について, DNA はジアミノ安息香酸螢光法 (DABA 法) (ThOMAS and FARQUHAR, 1978), RNA はオルシ
ノール法（SCHNEIDER, 1957）により定量した。ま た底泥の全リン量は ANDERSEN の方法（1976）によ り定量した。

\section{2-3. 沈降物の測定法}

震生湖の湖心において, 広ロビン（径 $7 \mathrm{~cm} \times$ 高 さ $15 \mathrm{~cm}$ ）を水深 $1.5 ， 4 ， 8 \mathrm{~m}$ の位置に 16 日間 吊し（1988年6月 29 日ー7月 15 日）ここに沈 積した沈降物を補集した。この沈降物の DNA, RNA 含量を $2-2$ の方法で測定した。

\section{2-4. 底泥の DNA，RNA 分解活性の測定法}

底泥 $7.5 \mathrm{~g}$ (湿重量) を三角フラスコに取り，こ れに静菌のためクロロホルム $3.8 \mathrm{ml}$ と $20 \mathrm{ml}$ の隇 菌水を加え, $25^{\circ} \mathrm{C} て ゙ 1$ 時間放置した。その後 15 mg の DNA (Sigma Type I) またはRNA （Sigma Type III）を添加し，滅菌水を加えて全 量を $75 \mathrm{ml}$ とし, $25^{\circ} \mathrm{C}$ で振とうしながらインキュ ベーションを行った。経時的にその一部を抜き取 り, $3000 \mathrm{rpm}(1000 \times g)$ で遠心分離後, その上

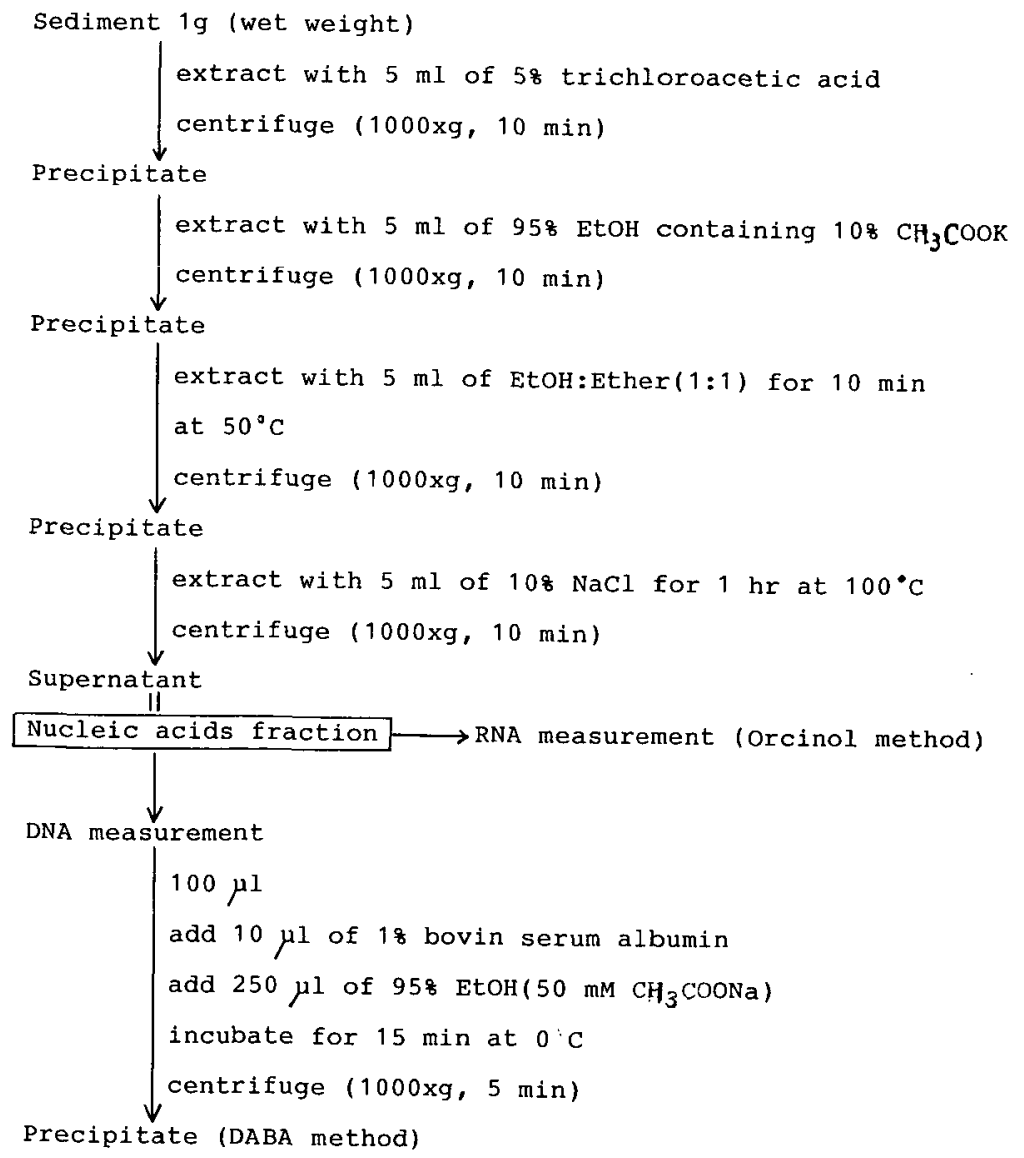

Fig. 1. Extraction procedure of DNA and RNA from sediment. 
澄 $5 \mathrm{ml} に 15 \%$ 過塩菜酸溶液 $1 \mathrm{ml}$ を加え, $4^{\circ} \mathrm{C} て ゙$ $10000 \mathrm{rpm}(7000 \times \mathrm{g})$ で遠心分離して未分解の DNA またはRNA を沈殿させた。この上澄につい

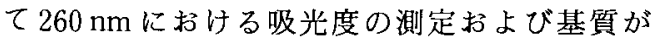
DNA の場合はデオキシリボースの定量（MAEDA and TAGA, 1973), RNAの場合はリボースの定量 (SCHNEIDER, 1957) を行った。デオキシリボース (Sigma), リボース (Sigma) を用いて各定量法に より検量線を作成し，これにより上澄中のDNAま たはRNA の分解物をデオキシリボースまたはリボ 一ス濃度として求めた。また同時に上澄のオルト リン酸も定量した（STRICKLAND and PARSONS, 1968）。空試験として底泥のみ，あるいはDNA, RNAのみをそれぞれ同様に操作した。活性值の算 出にはこれらの値を各測定值から差し引いて補正 した。

\section{2-5. 底泥のホスファターゼ活性の測定法}

底泥のホスファターゼ活性は $p$-ニトロフェニル リン酸を基質として用い, TABATABAI and BREMMER（1969）の方法により測定した。

\section{2-6. 底泥による DNA, RNA の分解経過のゲ}

\section{ルクロマトグラフィー}

2-4 と同様に牛込嫁底泥と DNA またはRNA と を混合し $25^{\circ} \mathrm{C} て ゙ 24$ 時間インキュベーションした溶 液の上澄 $6 \mathrm{ml}$ について, ゲルクロマトグラフィー を行った。カラムは, DNA の場合は Sephacryl S -200 (Pharmacia) $(1.8 \times 90 \mathrm{~cm})$, RNAの場 合 $\mathrm{cm}$ )を用い, 溶出溶媒は $0.1 \mathrm{M}$ ホウ酸緩衝液

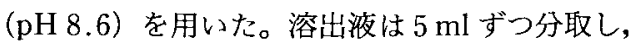
$260 \mathrm{~nm}$ の吸光度測定とオルトリン酸定量 (STRICKLAND and PARSONS, 1968) を行い, さらに 各溶出液にペルオキソ 2 硫酸カリウムを添加して オートクレーブ処理をした後，オルトリン酸測定 を行うことにより全リンを定量した。標準物質と して DNA (Sigma Type I), RNA (Sigma Type III), adenosin ${ }^{-5 \prime}$ monophosphate (Sigma), adenin (Sigma), adenosin (Sigma) を用い, 溶 出位置を調べた。

\section{3. 結果および考察}

\section{3-1. 底泥の DNA および RNA 含量}

調查した 4 水域の底泥中の DNA 濃度, RNA 濃度, リン濃度を Table 1 に示した。MAEDA and TAGA（1973）は駿河湾底泥のDNA 濃度は3.2$34.6 \mu \mathrm{g} \cdot \mathrm{g}^{-1}$ 乾重量と報告しているが, 今回の湖底 泥の測定值もこれに近い值を示していた。1987 年 に測定した 4 水域の表層水のクロロフィル濃度を あわせて示したが, それから判断すると，牛込濠， 手賀沼は, 富栄養化程度が高く, 植物プランクト ン生産が大きいのに対し, 赤城大沼は富栄責化程 度の低い湖と考えられる。牛込嫁, 手賀沼では底 泥中の全りン量が赤城大沼に比べて著しく高かっ た。しかし，DNA とRNAの量は䣄リン量の大小 とは対応していなかった。DNAやRNAにはリン が約 $9 \%$ 含有されていることから，底泥中の全り ン量のうちの核酸由来のリンの占める割合を算出 すると，9-24\%となった。

Table 1. DNA, RNA and total phosphorus contents in bottom sediments and newly sedimented matter.

\begin{tabular}{|c|c|c|c|c|c|}
\hline Samples & $\begin{array}{c}\text { DNA } \\
\left(\mu \mathrm{g} \cdot \mathrm{g}^{-1}\right. \\
\text { dry wt. })\end{array}$ & $\begin{array}{c}\text { RNA } \\
\left(\mu \mathrm{g} \cdot \mathrm{g}^{-1}\right. \\
\text { dry wt. })\end{array}$ & $\begin{array}{c}\text { Total } \\
\text { phosphorus } \\
\left(\mu \mathrm{g} \cdot \mathrm{g}^{-1}\right. \\
\text { dry wt. })\end{array}$ & $\begin{array}{c}\text { Nucleic acid-P } \\
\text { ratio }^{a)} \\
(\%)\end{array}$ & $\begin{array}{l}\mathrm{Chl}-a^{b)} \\
\left(\mathrm{mg} \cdot \mathrm{m}^{-3}\right)\end{array}$ \\
\hline \multicolumn{6}{|l|}{ Sediments } \\
\hline Ushigomebori (9 May. 1988) & 81.4 & 2318 & 2547 & 9 & 114.5 (May) \\
\hline Teganuma ( 8 Oct. 1988) & 3.6 & 1268 & 1151 & 10 & 50.5 (October) \\
\hline Shinseiko. (29 Jun. 1988) & 67.0 & 1100 & 709 & 15 & 29.3 (July) \\
\hline Akagi-Ono ( 8 Jul. 1988) & 22.5 & 2105 & 802 & 24 & 2.0 (July) \\
\hline \multicolumn{6}{|l|}{ Newly sedimented matter ${ }^{c)}$} \\
\hline at $1.5 \mathrm{~m}$ & 34.9 & 5775 & - & - & \\
\hline $4 \mathrm{~m}$ & 158.0 & 6102 & -- & - & \\
\hline $8 \mathrm{~m}$ & 165.0 & 7109 & - & - & \\
\hline
\end{tabular}

a) Nucleic acid-P ratio $(\%)=($ Nucleic acid $-\mathrm{P}) \times(\text { Total-P })^{-1} \times 100$.

Nucleic acid-P $=($ DNA + RNA $) \times 0.09$.

b) Chlorophyll $\sim a$ concentrations in the surface layer measured in 1987 .

c) The newly sedimented matter was collected in Shinseiko from 29 June to 15 July 1988. 
湖水中の DNA, RNA 濃度は, 従来水中の生物 量を示す一指標として用いられており（HoLmHANSEN et al., 1968; IWAMURA et al., 1970), 前 田・富岡（1977）は日本の15 湖沼水中の懸濁態 DNA，RNA 濃度を測定した結果，それぞれ 1.0$46.8 \mathrm{mg} \cdot \mathrm{m}^{-3}, 24-2086 \mathrm{mg} \cdot \mathrm{m}^{-3} て ゙$, 富栄養湖で は貧栄養湖に比べて高濃度であったと報告してい る。湖水中の懸濁物の一部は徐々に底泥へ沈降し て行くと考えられること加ら, 水深 $8.5 \mathrm{~m}$ の震生 湖に㧈いて上層 (水媣 $1.5 \mathrm{~m}$ ), 中層 $(4 \mathrm{~m})$, 底層 $(8 \mathrm{~m})$ で 16 日間の沈降物を捕集し，そのDNA お よびRNA 含量を測定した（Table 1)。上層, 中 層に比べると底層での捕集物の方が DNA， RNA 含量が高い傾向があった。これは表層の植物プラ ンクトンを中心とする眸濁物質が下層へ沈降して いる際に細菌や原性動物などの分解性微生物の付 着を受けるためか，あるいは䋰濁物質が沈降する ときに核酸以外の構成物質がより速く分解を受け るためかもしれないが，今後の研究が必要である。

上記の上うな核酸を含む沈降物が底泥に蓄積し ていくので，底泥中の DNA，RNA は底泥に棲息 している微生物に由来するものばかりでなく, 水 中から沈降してきた植物プランクトン遺䯚等に由 来するものも含まれていると考光られる。

\section{3-2. 底泥中の DNA， RNA 分解活性}

牛込嫁の底泥による DNA, RNA の分解生成物 の経時変化を Figure 2 と 3 に示した。DNAや RNA が分解されると, その構成成分からヌクレオ チド，ヌクレオシドまたは塩基, 糖類およびリン 酸が生成されることが予想されるが, 各インキュ ベーション溶液の上澄では, 塩基成分に由来する と思われる $260 \mathrm{~nm}$ の吸収（日本化学会, 1958) とデオキシリボースまたはリボース濃度が増加し た。また同時に溶液中のオルトリン酸濃度が增加 した。

Figure 4 と 5 に牛込嫁底泥と DNA または RNA を 0 および 24 時間インキュベーションした溶液の ゲルクロマトグラムを示した。DNAの場合, 24 時 問後にはDNA のピークが減少し，低分子領域にリ ン濃度では $V_{e} \cdot V_{0}^{-1}=2.5, \mathrm{~A}_{260}$ では $V_{e} \cdot V_{0}^{-1}=$ $2.8,3.2,3.5$ のピークが出現した。これらのピー クは底泥のみをインキュベーションした溶液のゲ ルクロマトグラフィーでは増加せず, DNA の分解 産物と考えられる。 $V_{e} \cdot V_{0}^{-1}=2.5$ のピークは才ル トリン酸のピークであるが, 他のピークはリンを 含んでおらず標品のアデノシン等と溶出位置が近 いことから，DNA 構成成分のヌクレオシド類ある いは塩基類が溶出されていると考光られる。DNA 画分とオルトリン酸画分以外にリンを含む画分は
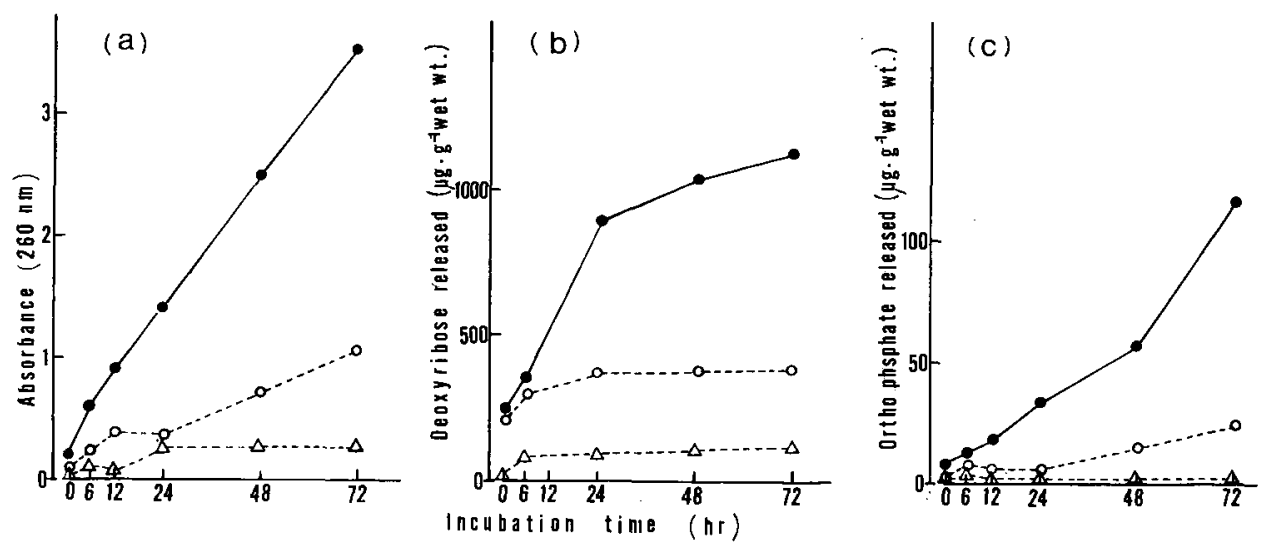

Fig. 2. Decomposition of DNA during the incubation with Ushigomebori sediment at $25^{\circ} \mathrm{C}$.

(a) Absorbance at $260 \mathrm{~nm}$ in the supernatant of the incubation mixture.

(b) Amount of deoxyribose $(\mu \mathrm{g})$ released from Ushigomebori sediment (1g wet weight) during the incubation.

(c) Amount of ortho-phosphate $(\mu \mathrm{g})$ released from Ushigomebori sediment (1g wet weight) during the incubation.

- - mixture of DNA and Ushigomebori sediment

O-...- : mixture minus DNA

$\triangle \cdots \triangle$ : mixture minus sediment 

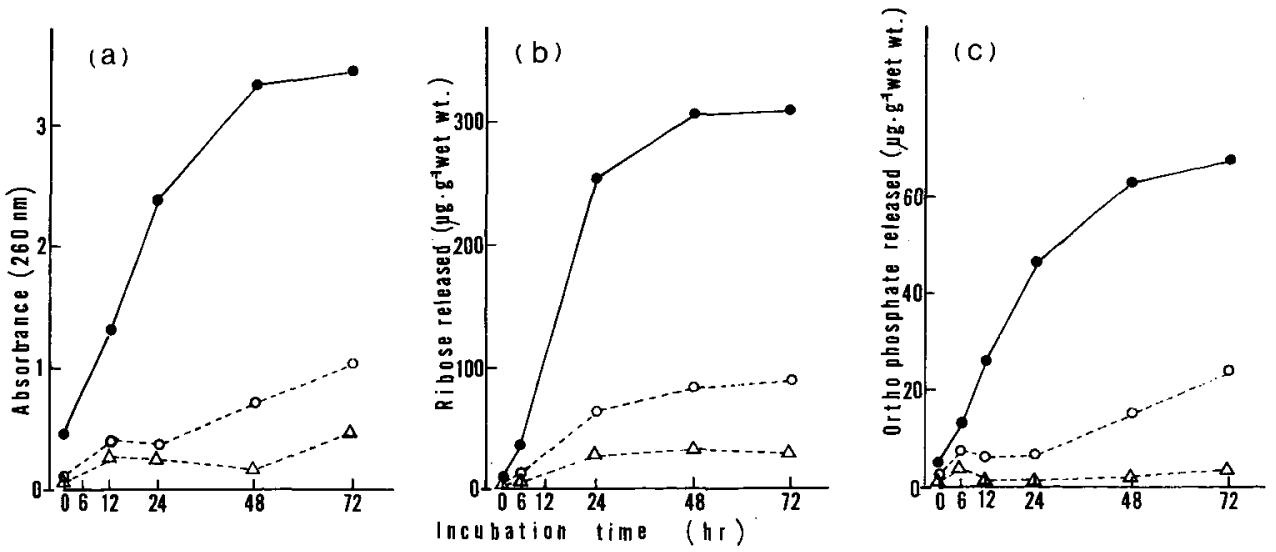

Fig. 3. Decomposition of RNA during the incubation with Ushigomebori sediment at $25^{\circ} \mathrm{C}$.

(a) Absorbance at $260 \mathrm{~nm}$ in the supernatant of the incubation mixture.

(b) Amount of ribose $(\mu \mathrm{g})$ released from Ushigomebori sediment (1g wet weight) during the incubation.

(c) Amount of ortho-phosphate $(\mu \mathrm{g})$ released from Ushigomebori sediment (1g wet weight) during the incubation.

- - mixture of RNA and Ushigomebori sediment

O-...- : mixture minus RNA

$\triangle \cdots-\triangle$ : mixture minus sediment

Table 2. Activities of DNA and RNA decomposition and production rate of orthophosphate during the incubation of bottom sediments.

\begin{tabular}{lccccc}
\hline \multirow{2}{*}{ Samples } & \multicolumn{2}{c}{ Substrate DNA } & & \multicolumn{2}{c}{ Substrate RNA } \\
\cline { 2 - 3 } & $\begin{array}{c}\text { Decomposition } \\
\text { activity }^{a)}\end{array}$ & $\begin{array}{c}\text { Ortho-phosphate } \\
\text { production }^{b)}\end{array}$ & & $\begin{array}{c}\text { Decomposition } \\
\text { activity }^{c)}\end{array}$ & $\begin{array}{c}\text { Ortho-phosphate } \\
\text { production }^{b)}\end{array}$ \\
\hline Ushigomebori & 15.5 & 1.07 & & 6.29 & 1.70 \\
Teganuma & N.D. & N.D. & & 0.34 & 0.25 \\
Shinseiko & N.D. & N.D. & & N.D. & N.D. \\
Akagi-Ono & N.D. & N.D. & & N.D. & N.D. \\
\hline
\end{tabular}

a) $\mu \mathrm{g}$ deoxyribose $\cdot \mathrm{g}^{-1}$ wet sediment $\cdot \mathrm{hr}^{-1}$

b) $\mu \mathrm{g}$ ortho- $\mathrm{P} \cdot \mathrm{g}^{-1}$ wet sediment $\cdot \mathrm{hr}^{-1}$

c) $\mu \mathrm{g}$ ribose $\cdot \mathrm{g}^{-1}$ wet sediment $\cdot \mathrm{hr}^{-1}$

N.D.: not detected

Incubation temperature: $25^{\circ} \mathrm{C}$

認められなかった。RNAの場合も同様に，インキ ュベーション後に RNAのピークは隇少し, 分解産 物のオルトリン酸のピーク $V_{e} \cdot V_{0}{ }^{-1}=2.4$, 扔よび リンを含まないヌクレオシド類と考えられるピー ク $V_{e} \cdot V_{0}^{-1}=2.9,3.8$ が出現した。以上のように 牛込濠底泥とのインキュベーションにより DNA ま たはRNA は明らかに低分子化された。核酸を分解 する醉素としてはDNase，RNase，双方を分解す るヌクレアーゼがあるが(今堀・山川，1984），こ
れらは核酸よりオリゴまたはモノヌクレオチドを 生成する。一方, リン酸エステルを加水分解しリ ン酸を生成する醉素としてホスファターゼがある が,これはDNAやRNAに直接作用しない。 DNA，RNA と牛込濠底泥とのインキュベーショ ンでオルトリン酸の生成が認められたことから, これらの分解過程では底泥中の DNase, RNase あ るいはヌクレアーゼの作用のほかに, 分解生成物 のヌクレオチドからのオルトリン酸生成に関与す 

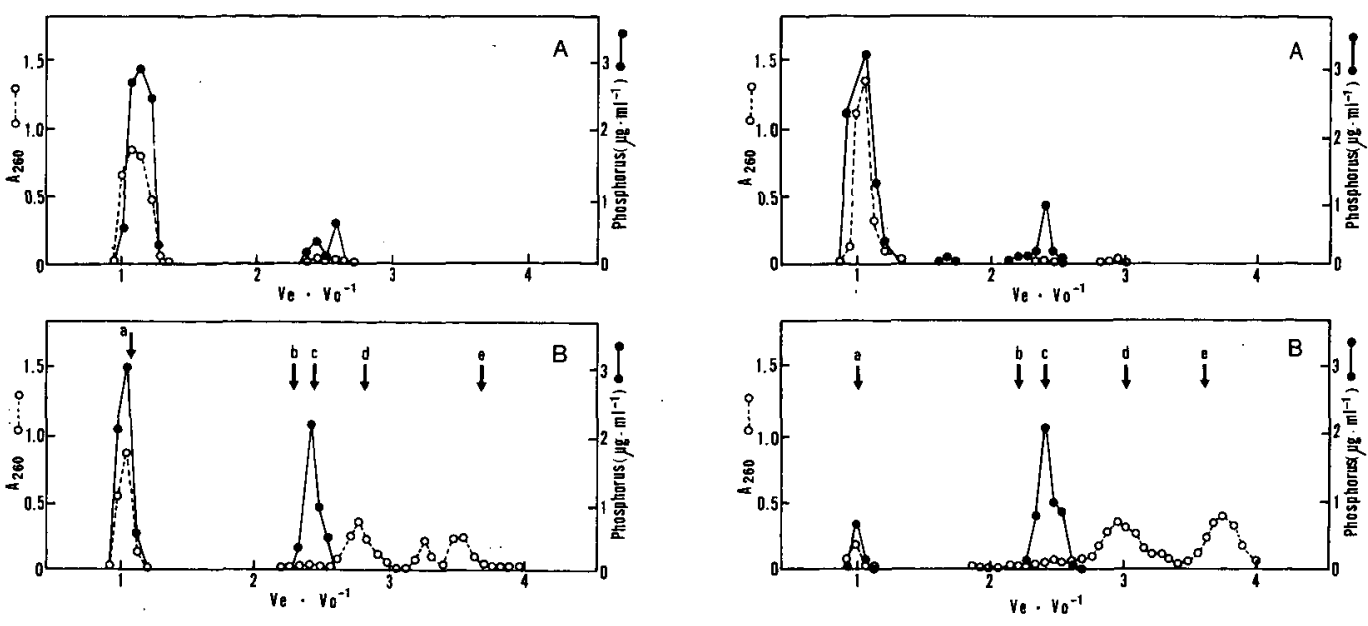

Fig. 4. Gel chromatogram of DNA before (A) and after (B) 24 hours' incubation with Ushigomebori sediment at $25^{\circ} \mathrm{C}$. Column: Sephacryl S-200 $1.8 \times 90 \mathrm{~cm}$ Eluent : borate buffer ( $\mathrm{pH} 8.6)$ - - : total phosphorus o.....- $0: A_{260}$

$\downarrow$ : elution point of standard compound a: DNA

b: adenosine $-5^{\prime}-$ monophosphate

c: ortho-phosphate

d: adenosine

e: adenine

Fig. 5. Gel chromatogram of RNA before (A) and after (B) 24 hours' incubation with Ushigomebori sediment at $25^{\circ} \mathrm{C}$.

Column: Sephadex G-50 $1.8 \times 90 \mathrm{~cm}$ Eluent : borate buffer (pH 8.6)

-——: total phosphorus

o.....-0: $\mathrm{A}_{260}$

$\downarrow$ : elution point of standard compound a: RNA

b: adenosine- $5^{\prime}$-monophosphate

c: ortho-phosphate

d: adenosine

e: adenine

Table 3. Effects of $\mathrm{pH}$ and temperature on DNA and RNA decomposition and orthophosphate production rate during the incubation of Ushigomebori sediment.

\begin{tabular}{|c|c|c|c|c|}
\hline & \multicolumn{2}{|c|}{ Substrate DNA } & \multicolumn{2}{|c|}{ Substrate RNA } \\
\hline & $\begin{array}{c}\text { Decomposition } \\
\text { activity }\end{array}$ & $\begin{array}{l}\text { Ortho-phosphate } \\
\text { production }\end{array}$ & $\begin{array}{c}\text { Decomposition } \\
\text { activity }\end{array}$ & $\begin{array}{c}\text { Ortho-phosphate } \\
\text { production }\end{array}$ \\
\hline & \multicolumn{2}{|c|}{ (relative rate \%) } & \multicolumn{2}{|c|}{ (relative rate \%) } \\
\hline $\mathrm{pH} \quad 8.7^{a)}$ & 100 & 100 & 100 & 100 \\
\hline $7.7^{a)}$ & 77 & 72 & 93 & 101 \\
\hline $6.7^{a)}$ & 63 & 11 & 55 & 23 \\
\hline \multicolumn{5}{|c|}{ Temperature } \\
\hline $25^{\circ} \mathrm{C}^{b)}$ & 100 & 100 & 100 & 100 \\
\hline $15^{\circ} \mathrm{C}^{(b)}$ & 15 & 36 & 58 & 57 \\
\hline $5^{\circ} \mathrm{C}^{6)}$ & 0 & 4 & 15 & 10 \\
\hline
\end{tabular}

a) Incubation temperature $25^{\circ} \mathrm{C}$.

b) Incubation $\mathrm{pH} 8.7$.

るホスファターゼ類の存在が予想される。牛込濠 の試料について $p$-ニトロフェニルリン酸を基質と してホスファターゼ活性を測定したところ, pH 8.8,
7.7，6.7でそれぞれ 48.9，38.5，12.1p-nitrophenol $\mu \mathrm{g} \cdot \mathrm{g}^{-1}$ wet sediment $\cdot \mathrm{hr}^{-1}$ とアルカリ側 でょり活性が高いホスファターゼ活性が測定され 
た。

4 水域の底泥による DNA，RNA の分解活性を Table 2 に示した。DNA, RNA の分解活性は 24 時間後の上澄中のデオキシリボース，またはりボ 一スの濃度から算出した。また，オルトリン酸の 生成速度を同様に算出した。DNA 分解活性は牛 込嫁の底泥にのみ, また RNA 分解活性壮牛込濠と 手賀沼底泥にのみ認められ, 震生湖, 赤城大沼の 底泥ではDNA およびRNA 分解生成物を検出でき なかった。DNA あるいはRNA の分解活性がみら れた底泥では同時にオルトリン酸の生成がみられ たが，DNA，RNA の分解がない底泥ではみられ なかった。

牛込涼底泥を用いた DNA，RNA 分解に対する $\mathrm{pH}$ ，温度の影響を Table 3 に示した。DNA， RNA の分解活性はいずれも中性から弱アルカリ性 で高かった。また, オルトリン酸の生成は DNA, RNA の分解に比べて $\mathrm{pH}$ の影響をより大きくうけ， 中性, 弱アルカリ性にくらべ弱酸性下では非常に 低い活性であった。また，温度が低いほど DNA， RNA 両分解活性は著しく減少し，オルトリン酸の 生成もこれと対応して減少した。

以上述べたように，本調査において淡水域底泥 にDNA，RNA 扔よび核酸分解活性が見いだされ た。核酸は構成成分としてリンや窒素を含むので, 底泥中で分解されて無機態のリンや窒素が生成し, それらが水中に回帰した場合には植物プランクト ン等の栄養塩類として再び利用されることが予想 される。従って底泥中の核酸濃度やその分解活性 の測定は, 水域全体の栄責状熊等を検討する上で も意義あると考えられる。今後さらに調査水域の 数, 回数を増やし, 地域的, 李節的変動の詳細な 調査や分解実験，核酸の由来の検討等を行う必要 があると考える。

\section{摘要}

牛込嫁, 手賀沼, 震生湖, 赤城大沼の底泥の DNA，RNA 濃度，および各底泥にクロロホルム を添加して静菌した状態下で，それらによる核酸 の酵素的分解活性を測定した。底泥中の DNA, RNA 濃度はそれぞれ 3.6-81.4 ( $\mu \mathrm{g} \cdot \mathrm{g}^{-1}$ dry wt.), 1100-2318（ $\mu \mathrm{g} \cdot \mathrm{g}^{-1} \mathrm{dry} w \mathrm{wt}$ ) であり，水中クロ ロフィル濃度が高い水域ほど両者の濃度は高かっ た。これら核酸画分のリンが底泥の総リンに占め る割合は 9-24\%であった。

DNA 分解活性は牛込涼, RNA 分解活性は牛 込濠，手賀沼底泥飞認められた。DNAまたは RNA と牛込濛底泥とのインキュベーション溶液の
ゲルクロマトグラフィーにより，インキュベーシ ヨン過程で核酸が低分子化され，リンを含んでい ない低分子化合物とオルトリン酸が生成すること を確認した。牛込濠の核酸分解活性は弱アルカリ 性およびインキュベーション温度が高いとき，よ り高かった。

\section{文献}

Andersen, J. M. (1976): An ignition method for determination of total phosphorus in lake sediments. Water Res., 10: 329-331.

Holm-Hansen, O., W. H. Sutcliffe Jr. and J. SHARP (1968): Measurement of deoxyribonucleic acid in the ocean and its ecological significance. Limnol. Oceanogr. 13: 507-514.

細見正明・須藤隆一 (1979): 湖沼底泥からのリンの溶 出に関する研究. 水質污濁研究, 2: 157-162.

今堀和友 -山川民夫 (1984): 生化学辞典. 東京化学同 人

Iwamura T., H. Nagal and S. Ichimura (1970): Improved method for determining contents of chlorophyll, protein, ribonuceic acid, and deoxyribonucleic acid in planktonic populations. Int. Revue ges. Hydrobiol. 55: 131-147.

小林節子・西村肇 (1988 a): 好気下における底質からの リンの溶出に及ぼす錯形成物質の影響．水質污滥 研究, 11: 693-701.

小林節子・西村肇 (1988b): 底質加らのリンの溶出にお ける $\mathrm{Fe}$ (II) とリン酸イオンの挙動。水質污濁研 究, 11: 755-764.

Maeda, M. and N. Taga, (1973): Deoxyribonuclease activity in seawater and sediment. Mar. Biol., 20: 58-63.

MAEDA, M. and N. TAGa (1974): Occurrence and distribution of deoxyribonucleic acid-hydrolyzing bacteria in sea water. J. Exp. Mar. Biol. Ecol., 14: 157-169.

前田修・富岡英通 (1977): 本州中部湖沼の夏季におけ るけん濁態タンパク質および核酸の鉛直分布. 陸 水雑, 38: 109-115.

Mortimer, C. H. (1971): Chemical exchanges between sediments and water in the Great Lakes-speculations on probable regulatory mechanisms. Limnol. Oceanogr., 16: 387-404.

中島淳・金子光美 (1988)：湖底泥中有機態リンの分子 量分布. 陸水雑, 49: 205-212.

日本化学会 (1958): 実験化学講座 24. 丸善株式会社.

SCHNFIDER, W. C. (1946): Phosphorus compounds in animal tissues III A composition of methods for the estimation of nucleic acid. J.Biol.Chem., 164: 747-751.

Schneider, W. C. (1957): Determination of nucleic 
acids in tissues by pentose analysis. Methods in Enzymology., 3: 680-684.

Sommers, L. E., R. F. Harris, J. D. H. Williams, D. E. Armstrong and J. K. Syers (1972): Fractionation of organic phosphorus in lake sediments. Soil Sci. Soc. Amer. Proc., 36: 51-54.

スタム W.・モーガン J. J. (1970): 一般水質化学 下. 共立出版.

Strickland, J. D. and T. R. Parsons (1968): A practical handbook of seawater analysis. Fish. Res. Bd. Can., 167: 49-64.

Tabatabai, M. A. and J. M. Bremmer (1969): Use of $p$-nitrophenyl phosphate for assay of soil phosphatase activity. Soil Biol. Biochem., 1: 301-307.
Thomas, P. S. and M. N. FARquhar (1978): Specific measurement of DNA in nucleic acid using diaminobenzoic acid. Anal. Biochem., 89: 3544.

（著者：田畑真佐子・渡辺昇 -今川直美 - 鈴木静夫, 東京理科大学薬学部, $\bar{\top} 162$ 新宿区市々谷船河原町 12; Masako Tabata, Noboru Watanabe, Naomi IMAGawa and Shizuo Suzuki, Faculty of Pharmaceutical Science, Science University of Tokyo, 12 Ichigaya Funagawara-machi, Shinjuku-ku, Tokyo 162.)

1990 年 2 月 1 日 受付 1990 年 12 月 26 日 受理 